付近での象牙質とりン酸雨鉛セメントとの膨張準が近似 していることは, 通常, 口腔内でみられる温度変化に伴 う象牙質の熱膨張と，リン酸曲鉛セメントのそれとがよ く一致するてとを意味している。乙のセメントが，種々 の久点があるにもかかわらず，好んで用いられる理由の 一つはここにあるといえるであろう。

\section{5. 開業歯科医院における散乱線の分布}

$$
\begin{aligned}
& \text { ○小川 和久 - 加治 俊夫 ·大塚 洋一 } \\
& \text { 近藤 彰・原田 吉通・和田 忠子 } \\
& \text { 森進一郎福霜大・歯放) }
\end{aligned}
$$

菊科診療における放射線防護の奏態を知るための手が 加りして，一般開業䨑科医院18力所の協力を得て，歯 科化扔けるX線撮影時の散乱線の测定を行った。今国 は, 特にバノラマ撮影時の散乱線の測定結果について報 告する。

測定に用いた線量計は，電離箱式サーベイメーター ALOKA ICS-151, ビクトリン470A で，X線の照射 条件は，実際にその医院で通常に使用している条件を用 いた。

測定を行った18医院のうち，16医院でパノラマ撮影装 㯰が設置されていた。乙れらの医院は，X線を有し，そ のゆで撮影を行っている医院のグルーブ, 診療室の一陆 に鉛衝立等の防護設備で囲って撮影を行っている医院の グループ, 診療室内で何ら防護設㒉無しに撮影を行って いる医院のグルーブと，3つのグルーブに大別するとと ができる。

第 1 のグループには， 6 医院が属し，放射線防護に対 する前向きの姿勢が見られた。第 2 のグルーブには 3 䂏 院，第 3 のグルーブには 7 医院が属し，それぞれの医院 の状況に応じた散乱線の分布結果を示した。

今回の調査において，歯科医師の放射線防護に対する 関心の度合は高まってきているが，その実状はまだ充分 でないととがわかった。

\section{6. 半月状神経節細胞に関する実殹的研究}

\section{○塩川 雅治・福山宏・上野 正康}

(九歯大 $\cdot$ 口病)

末梢神経に切断等の侵襲を加えた時の所属神経節細胞 への影響に関する研究は, 数多くなされている.又, 三 叉神経領域でも多くの報告がある。しかし，歯栺通内神経 破壊した時の半月状神経節細胞の变化に関する研究
は，極めて少ない。

1. 垁験方法・锶察方法

実験動物として，ウィスター系成熟ラットを使用し た・ソムノペンチルによる腹腔内麻酔を施し, 左側第 1

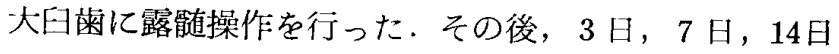
目にと殺した。生食水滴下に, 半月状神経節を摘出後, 神経染色用固定液に投入した。通法良い，パラフィン 包埋後, $5 \mu$ 連続切片を作製した。 この切片にニッス 儿染色, ヘマトキシリンとPASの重染色, 神経染色を 施し観察した。

2. 結果

(a) 対照群の所見

先人の報告とほぼ一致した。

(b) 開放露髅後 3 日目の所見

神経細胞に，軽度の萎縮が認められた。ニッスル 顆料に変化が見られたが，神経突起や神経線維に変 化は認められなかった。

(C) 開放露髅後 14 日目の所見

3 日例より強い萎縮を認め, 核之原形質の区別し 難い細胞や核の偏位した細胞を認めた。しかし，神 経突起や神経線維に変化は見られなかった。

3 日例，14日例ともに，神経細胞に変化が観察され た・変化の見られた細胞以外にも，未だ正常と思える細 胞が多数認められた。 今回は，3日例，7日例，14日例 について検索したが，7日例と14日例は，ほぼ同様の所 見が観察されたので，3 日例と14日例について発表し た。

\section{7. ペリオの興味ある臨床例}

\section{○津再実・西本美恵子・豊島 雅子 井上 龍彦・山本 博武}

(九歯大·保存 2 )

蒾周疾患の治療, 予防における plaque control の 重要性は言うまでもない，その最も一般的な方法として brushing が行われており，てれが霜周疾患の予後を左 份するにもかかわらず日常臨床において brushing 指 導の難かしさを感じさせられる現状である.

Brushing を実践するのは患者自身であり，永続させ るにはその意義を十分認識させるための motivation が必要となる。

Motivation とは, 人が何らかの行動を起こすように 動機づけをすること，即ちやる気を起こさせることであ り，巣に人に知識を与えて理解させる education とは 
異っている.

今回演者らは motivation の効果を把握したいと考 え臨床実験行い興味ある知見を得たので報告した。

被験者は外来㗲者 100 名であり，池野らの方法に従っ て3群江分け，1 週，2週後の plaque score と gingival score を比較した。菌口清掃の診査は Butler 社 のRed cote で染色し, Medical Nikkor t使用し Kodacolor II で 1.5倍传影し, U.S. Navy Plaque Index の基準沉従い部洒した. Brushing 指尊は Butler 社の soft, medium \#311,300 を使肪し, Scrubbing 法, Bass 法を併用した。

Motivation は「なぜ歯を磨かねばならないか」とい うことを一定の slide 在使用して行った。

その結果, motivation 在行った群がDlaque score, gingival score とも他の群と比較して有意の养があっ た.

このことから brushing 指導を行う場合には, 単に 技術指導のみを行うよりも患者に主体性を持って「やる 父」在起こさせ継続していこうとする強い意志をもたせ ることが必要であると考える。

\section{Odontoma の一例}

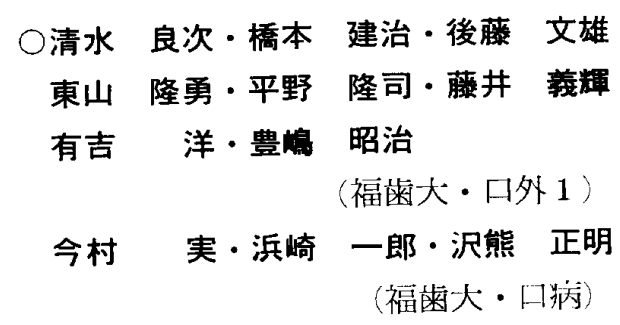

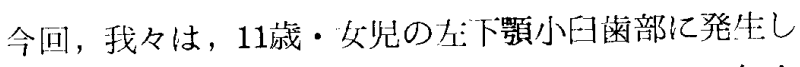
大小様々な歯牙様構造物扔よび石灰化物総計84個を包含 していた比較的稀な症例に遭遇したので臨床的, 病理組 織学的ならびに文献的考察を加えその概略を報告した。

患者は，左下頱小臼歯舌側㐘肉部の不快感を主泝として 昭和 55 年 3 月 21 日, 某歯科医院の紹介に依り来院した。 家族歴および既往暦に特記事項なし、日腔内所見では cd は残存し，同部舌側歯肉部汇直径約 $5 \mathrm{~mm}$ の表面料

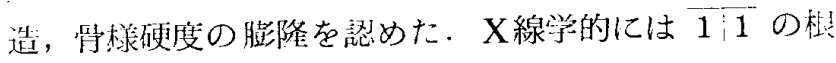
尖部に $\sqrt{3}$ が埋伏し，さらに $\sqrt{2}$ 根尖部より埋伏してい 万原の菌冠部们けて大小無数の塊状物を呈する拨指 頭大の不透過像が浔如られた. 以上より臨休竞断を歯牙 腫とし，3月27日 G-O-P 全身麻醉下に口腔内上り $\overline{\mathrm{cd}}$ および 3 を拔㫖すると其に結合織性被膜に包用された 腫瘤圭全摘出した，摘出腔には平川の推賞する即時自家

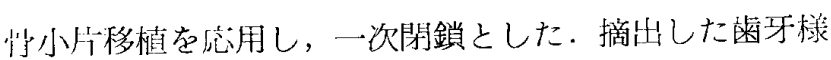
棈造物抢よび石灭化物を詳細に観察した後, 比較的隶牙 に近い形を古しているものと，咭していないもの2 個を 選び病理組織学的検索を行い, 病理組織学的診断を集合 性蒾牙腫之得た。

本疾患の好発部位は，一般に，下顎大曰歯部之言わ れ, 本症のごとく下喕小曰菌部门発生した例は比較的稀 なものであり，また，摘出した歯牙様構造物および石庅 化物の数は，我々の渉編し得た文献によると泉の 250 㫦，垃軍ら拉よび二瓶らの106個，金报らの98個沉次い で多い将例であった。

\section{9. 台湾先住民族の形質人類学的研究}

2. アミ族 (14歳) 頭顔部の計測について

\begin{tabular}{|c|c|c|}
\hline D六反 & 田篤・伊東 & 励-毛利 羏秀 \\
\hline 加藤 & 喜陸・村上 & 守良·山田 \\
\hline & & (九匊大· ·解 1 \\
\hline 田 & 彰・宮崎 & 秀夫 \\
\hline 伊波 & 富夫・佐伯 & 榮一 \\
\hline & & 九菌大・[1衛 \\
\hline 仲西 & 修 & (九歯大・歯麻) \\
\hline 田 & 吉通 & (福霜大・歯放) \\
\hline 奥村 & 英彦 & 長大歯・ 口外 \\
\hline
\end{tabular}

台湾原住民宲山族は，現在10種族に分類されてい る、これらの原住民はインドネシアンまたはプロトマレ イに属するといわれているが，体質的には短頭，短身な どの特徵があるとされている・しかしながら，かならずし も一様ではなく，なかでも Ami 族は他種族と異なり舆 頭，垃身の形質をホしている。演者らは Ami 族の中学 生（14藏）の頭顔部の生体計測を行ったので，その結果 在報告する。調查は1979年12月，台東県の東河郷の国民 中学校に在籍する男78名，女58名を調查対象とした。調 査項目は, 頭最大長, 頭最大幅, 頭耳高, 㸇骨号幅, 下 㖽角幅, 形態顔面高, 畒貌顔面高, 外眼角幅, 内眼角幅, 瞳孔間幅, 眼裂幅, 鼻高, 鼻幅, 口裂幅, 上粘膜唇高, 下粘膜㝴高である，以_ヒの計測値より頭長幅示数，頭長 漓示数, 頭幅高示数, 形態顔面示数, 下類示数, 横頭顔 示数, 垂直頭顔示数, 鼻示数を算虫し, 検討した。

その結果の概要は次のごとくである。

頭最大铱：罗 $181.7 \mathrm{~mm}$ ，女 $177.2 \mathrm{~mm}$.

頭最大幅：男 $145.6 \mathrm{~mm}$, 女 $142.5 \mathrm{~mm}$.

煩骨弓幅：男 $136.7 \mathrm{~mm}$ ，女 $133.0 \mathrm{~mm}$.

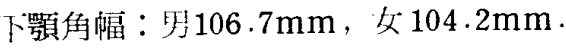

